\title{
Influence of seed priming with salicylic acid on germination and early growth of sesame
}

\author{
Farhan Ahmad ${ }^{1}$, Shahid Iqbal' ${ }^{2}$, Muhammad Rabnawaz Khan ${ }^{1}$, \\ Muhammad Waseem Abbas ${ }^{1}$, Junaid Ahmad ${ }^{1 *}$, Haq Nawaz ${ }^{1}$, Sayed \\ Minhaj Ali Shah ${ }^{1}$, Sarmad Iqbal ${ }^{1}$, Manzoor Ahmad ${ }^{1}$ and Mehran Ali $^{1}$ \\ 1. Department of Agronomy, Faculty of Crop production sciences, The University of Agriculture Peshawar- \\ Pakistan \\ 2. Department of Agronomy, Faculty of Crop production Sciences, The University of Faisalabad-Pakistan \\ *Corresponding author's email: junaid.agri@aup.edu.pk \\ Citation \\ Farhan Ahmad, Shahid Iqbal, Muhammad Rabnawaz Khan, Muhammad Waseem Abbas, Junaid Ahmad, Haq \\ Nawaz, Sayed Minhaj Ali Shah, Sarmad Iqbal, Manzoor Ahmad and Mehran Ali. Influence of seed priming \\ with salicylic acid on germination and early growth of sesame. Pure and Applied Biology. Vol. 8, Issue 2, \\ pp1206-1213. http://dx.doi.org/10.19045/bspab.2019.80062
}

\begin{tabular}{llll}
\hline Received: 10/01/2019 & Revised: 08/04/2019 & Accepted: 10/04/2019 & Online First: 18/04/2019 \\
\hline
\end{tabular}

\section{Abstract}

An experiment was conducted at Agronomy Laboratory of AMK Campus Mardan, The University of Agriculture Peshawar during kharif 2017 to investigate the influence of seeds priming of salicylic acid on sesame germination and early growth. The experiment was comprised on seed priming with different level of salicylic acid solutions $(0.1 \%, 0.2 \%, 0.3 \%$, $0.4 \%, 0.5 \%, 0.6 \%, 0.7 \%, 0.8 \%$ and $0.9 \%$ ). Ten seeds of sesame local black was sown in each petri dish. Seed priming with $0.9 \%, 0.8 \%$ and $0.7 \%$ of salicylic acid solutions took less days to germination (7.6) while dry seeds took more days to germination (12.5). Germination percentage was noted maximum $(72.3 \%$ ) in $0.9 \%$ and $0.8 \%$ of salicylic acid solutions. Mean germination time was noted higher (1.07) where seeds were not treated to salicylic acid solutions. The taller seedling $(8.4 \mathrm{~cm})$ was recorded in $0.9 \%, 0.8 \%$ and $0.6 \%$ of salicylic acid solutions. Shoot weight of $\left(0.67 \mathrm{mg} \mathrm{plant}^{-1}\right)$ was found maximum in $0.9 \%$ and $0.7 \%$ of salicylic acid solutions, similarly root weight $\left(0.38 \mathrm{mg}\right.$ plant $\left.^{-1}\right)$ was higher in $0.9 \%$ of salicylic acid solutions. On the base of consequences it was determined that levels of salicylic acid $0.6 \%$ to $0.9 \%$ seed priming performed well for rapid germination and vigorously growth and hence it is recommended under agro-climatic condition of Mardan.

Keywords: Germination; Petri dish; Priming; Salicylic acid; Sesame; Soak

\section{Introduction}

Sesame (Sesamum indicum L.) have its place in family Pedaliaceae. It is selfpollinated, indeterminate and annual crop grown mainly for oil purpose. Fruit of sesame is capsule the size it diverges from 3.6 to $9 \mathrm{~cm}$ in length and a diameter of 0.6 to $2.2 \mathrm{~cm}$. Being a short-day crop, it begins flowering in 43 to 46 days. Seeds of sesame are small and egg-shaped with diverse forms, cream-colored and black. Creamedcolored seeds are favorite [1]. Sesame is chief edible oil seed. Entire seed of sesame is used for food purposes, cookies of cake and also bread. Its seed comprises of entirely compulsory minerals as consider that of phosphorous and calcium. Sesame is a decent cause of vitamins such as vitamin E [2].The crop also contains extraordinary worth of eatable oil (43-55\%) and protein 
(23 to $26 \%$ ). Its oil was great quantities of firmness and opposition to rancidity [3]. Oil of sesame is neutral, fragrance-free and consumes laterally shelf lifespan, which are mainly recycled for the purpose of soap, salad and cooking. [4]. Sesame is cultured on an area of about 77.6 thousand hectares by means of production yearly of 31 thousand tones and $401 \mathrm{~kg} \mathrm{ha}^{-1}$ average yield. In KP the typical yield is almost 100 $\mathrm{kg} \mathrm{ha}^{-1}[5]$.

Most of the features like water limitation, salinity, and extraordinary temperature are collective can bound the seed germination affecting reductions in the physiological feature and complex weakening [6]. Moreover the postponement in seedling growing and emergence was likewise detected in rice under circumstances of restriction of water [7]. In roughly circumstances, this kind of constant worry can take to a whole restriction of emergence of seedling [8], being this limitation, predominantly initiated by the lessening of the fascination of water throughout the imbibition that upsets the action of enzymes elaborate in the process of germination [9]. Priming of seed processing is a pre-sowing approach for plantlet improvement through moderating pre propagation metabolic action earlier to rising of the radicle and largely enriches plant performance and germination amount [10]. Priming permits the seed to hydrate to beginner the primary proceedings of germination, but not allow emergence of radicle, monitored by dehydrating to early moistness [11]. The rumors that priming of seed allow timely replication of DNA, RNA growth and synthesis of protein, augments growth of embryo, conservations of declined seed portions and also diminishes outflow of metabolites. The techniques of priming of seed is understood as a feasible skill to augment speedy and emergence uniformly, better yields and great vigor in nearly some field crops [12]. Procedures of seed priming comprises of osmo-priming, hydro priming, matrix priming, salt-priming, and thermopriming [13]. Hydro priming is an identical, pre sowing behavior whereby seeds are dripping in liquid as that of water or other chemicals for a convinced time and desiccated earlier as that of sowing [14]. Like to additional priming procedures, hydro priming commonly boosts germination of seed and emergence of seedling even though there are exemptions. Salicylic acid (SA) are phenolic combinations, which is extensively used in plants and is now recognized as a hormonelike ingredient [15]. Salicylic acid performances as a latent antioxidants and non-enzymatic as well as a growth regulator of plant [16], which show an significant character in guideline of plant physiological periods comprising photosynthesis, [17] nitrate metabolism, growth, heat production [18], Encouragement on the seed germination [19].

Salicylic acid priming method improved germination underneath short temperature situation [20] and upgraded alarming tolerance faster, [21] conservation of tissue water substances synchronous, emergence of sesame by stimulation of antioxidants and lessen permeability of membrane [22]. The present filed trial was designed to assess the outcome of diverse levels of salicylic acid on priming of seed on performances of germination and on timely growth of sesame.

\section{Materials and methods}

To find out the influence of diverse levels of salicylic acid solutions on seed priming of sesame an experiment was conducted at Agronomy Laboratory at AMK Campus Mardan, The University of Agriculture Peshawar in summer 2017. Seed of sesame primed with water and different levels of salicylic acid for 16 hours.

Different level of Salicylic acid solutions $(0.1 \%, 0.2 \%, 0.3 \%, 0.4 \%, 0.5 \%, 0.6 \%$, $0.7 \%, 0.8 \%$ and $0.9 \%$ ). After priming, seeds were kept in open air for 2 hours to remove excess water and then sown in petri dishes. 10 seeds of sesame variety local black were sown in each petri dish on September 18, 2017. The seeds were 
allowed to grow and water was applied as needed. Local black variety of sesame was tested in the experiment.

\section{Results and discussion}

\section{Germination (\%)}

Data on germination percentage are shown in below graph. Statistical analysis of the records displayed that outcome of seed priming with different levels of salicylic acid solutions had non-significant effect on germination percentage. However higher germination $(72.3 \%)$ was recorded in seed priming $0.9 \%$, and $0.8 \%$ of salicylic acid solutions, followed by $0.7 \%$ and $0.6 \%$ solution of salicylic acid while lower germination \% (57.3) was recorded from dry seed. Similar result was reported by [23] that exposed that use of slight spell enriched percentage of germination of wheat seeds (Figure 1).

\section{Germination percentage}

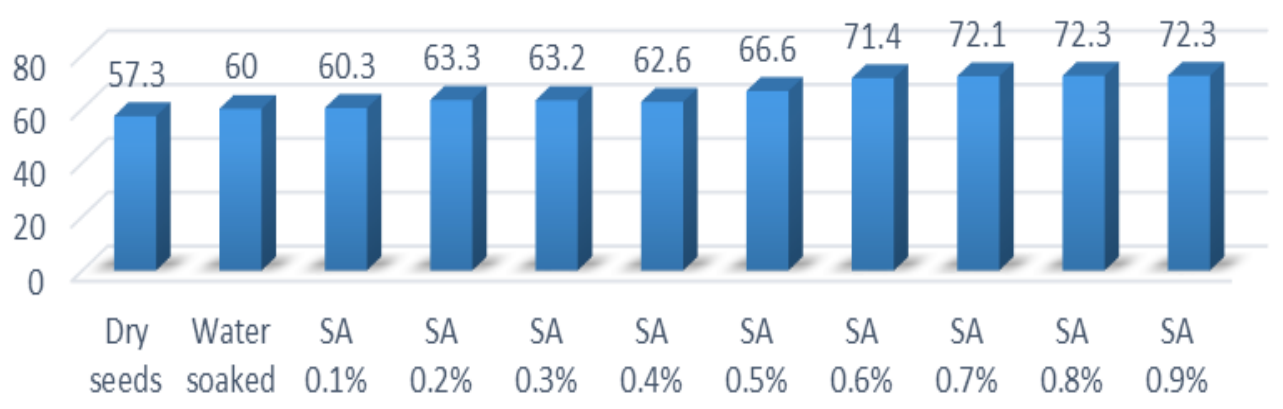

Figure 1. Germination percentage as influenced by seed priming with salicylic acid on germination and early growth of sesame

\section{Germination rate}

The data regarding germination rate is presented in the graph. Statistical analysis showed that effect of different levels of salicylic acid solutions had significant effect on germination rate. Higher germination rate (5.8) was noted in $0.9 \%$ and $0.8 \%$ solution of salicylic acid followed by $0.6 \%$ and $0.5 \%$ salicylic acid solution. The lower germination rate (2.2) was noted where seeds were not treated to salicylic acid solutions. These results are in closely related to [24] reported that significantly salicylic acid lessen the mean germination time and will enhance germination on yield (Figure 2).

\section{Germination rate}

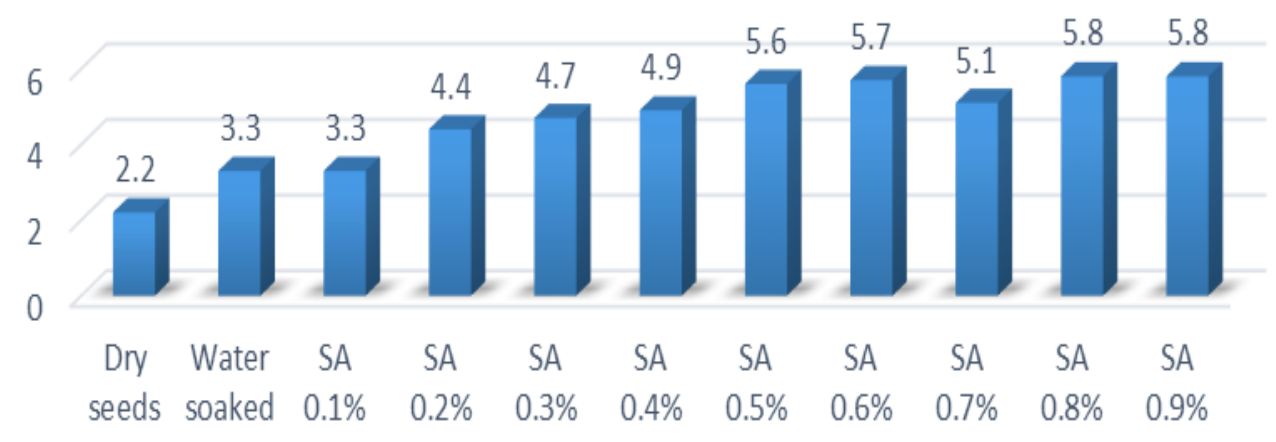

Figure 2. Germination rate as influenced by seed priming with salicylic acid on germination and early growth of sesame 
Mean germination time (Germination rate is performance of seed how well it grow and days to germination mean in how much days it will get germination) Mean germination time data is presented in graph underneath. Analysis of the data shown non-significant outcome of diverse levels of salicylic acid solutions on mean germination time. The higher mean germination time (1.07) existed in dry seeds, while the lower mean germination time $(0.91)$ was recorded in $0.9 \%$ solutions of salicylic acid. The results confirmed by [25] reported that significantly reduce the germination time (Figure 3).

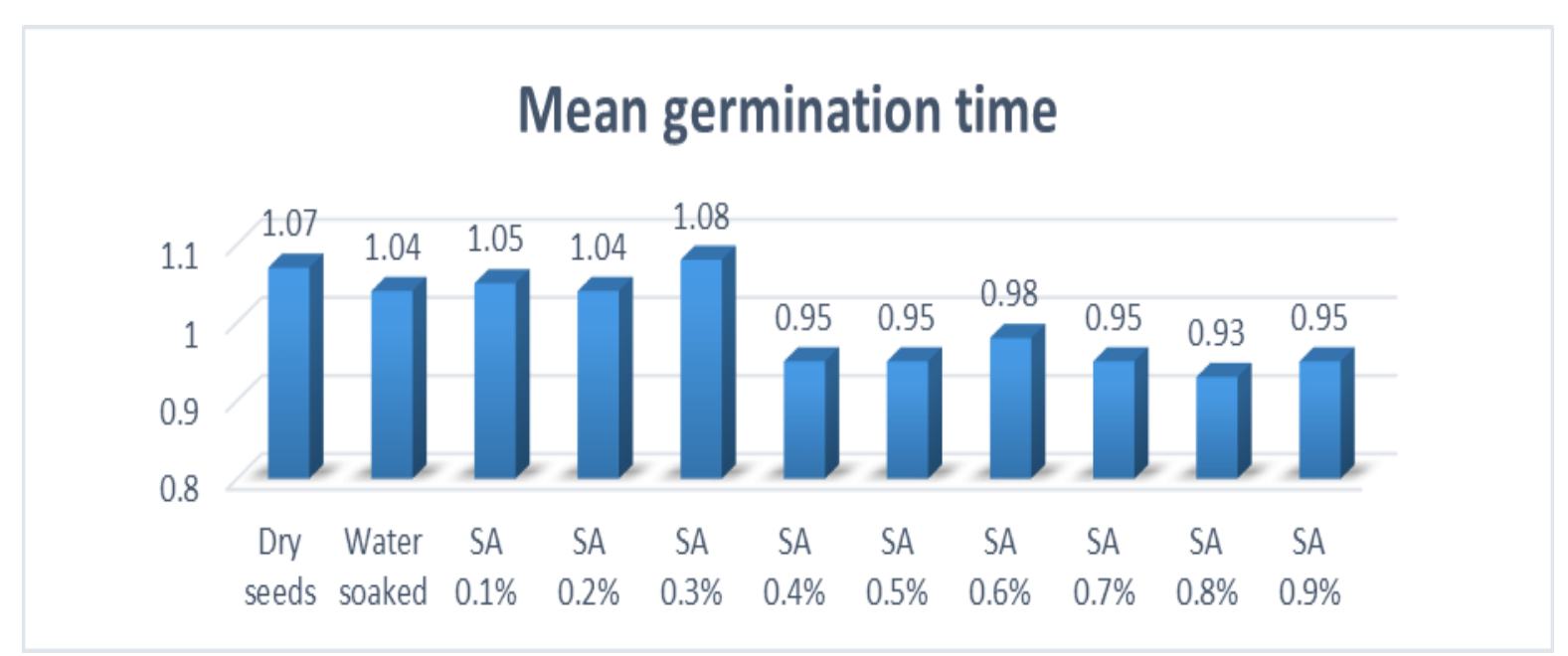

Figure 3. Mean germination time as influenced by seed priming with salicylic acid on germination and early growth of sesame

\section{Days to germination}

Data recording on days to germination shown in graph beneath. Analysis of the data showed significant conclusion of dissimilar levels of salicylic acid solutions on days to germination. More days to germination (12.5) were taken where seeds were not treated to any solutions, while less days to germination (7.6) were taken by $0.9 \%, 0.8 \%$ and $0.7 \%$ of salicylic acid solutions. These findings are in in line with those of the results of [26] (Figure 4).

\section{Days to germination}

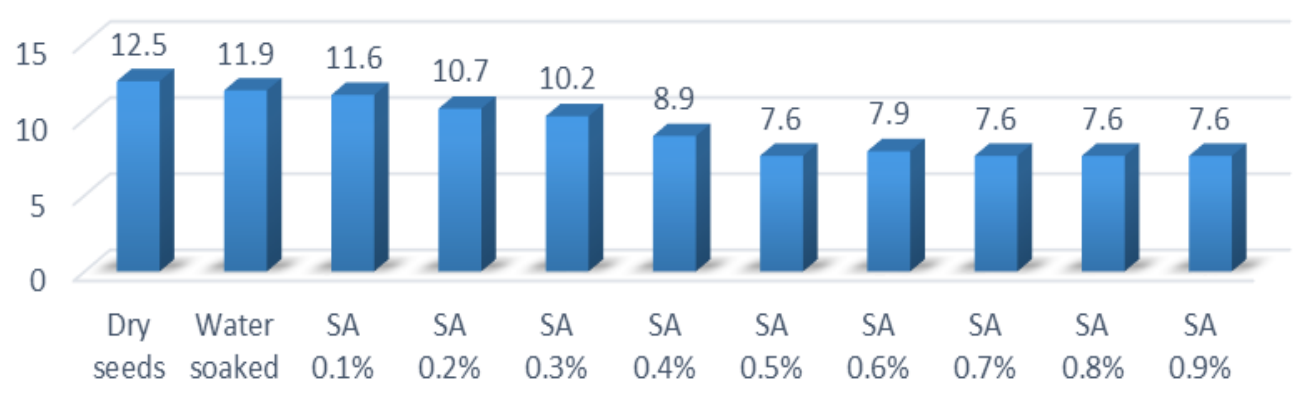

Figure 4. Days to germination as influenced by seed priming with salicylic acid on germination and early growth of sesame 
Seedling height $(\mathrm{cm}) 20$ days after sowing the seedling height was measured

Data concerning as that of the seedling height is existed in graph. Analysis of the data showed the influence of different levels of salicylic acid solutions had significant effect on plant height $(\mathrm{cm})$. The taller plant $(8.4 \mathrm{~cm})$ was noted in $0.9 \%$, $0.6 \%$ and $0.8 \%$ of salicylic solutions. The shorter plant $(6.4 \mathrm{~cm})$ was calculated in dry seeds. The same result was found on [27] (Figure 5).

\section{Seedling height $(\mathrm{cm})$}

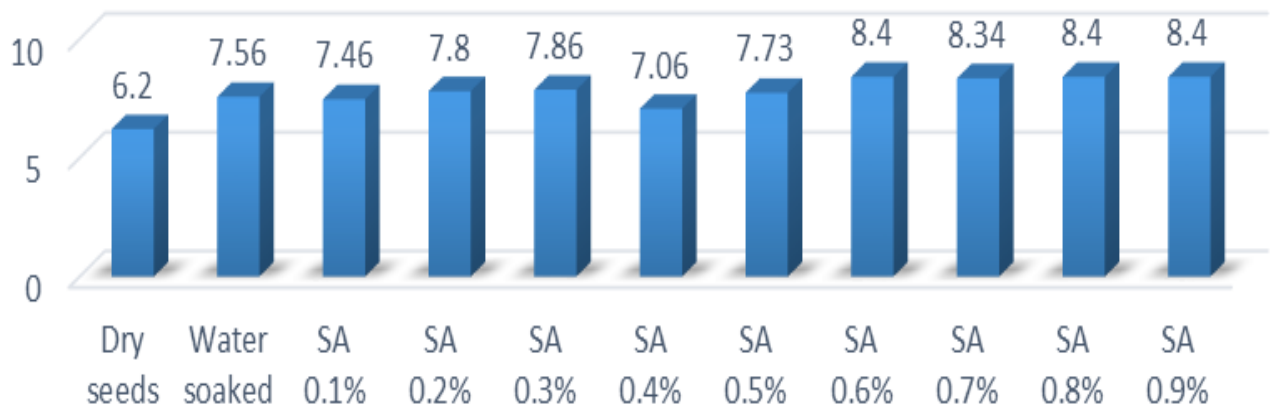

Figure 5. Seedling height $(\mathrm{cm})$ as influenced by seed priming with salicylic acid on germination and early growth of sesame

Shoot weight (mg plant ${ }^{-1}$ ) Shoot weight was recorded after seedling emergence Data recording on shoot weight is presented in graph. Statistical analysis of data showed significant effect of levels of salicylic acid solutions on shoot weight. The maximum shoot weight $\left(0.67 \mathrm{mg} \mathrm{plant}^{-1}\right)$ was noted in $0.9 \%$ and $0.7 \%$ of salicylic acid solutions. Minimum shoot weight $\left(0.53 \mathrm{mg}_{\text {plant }}{ }^{-1}\right)$ was noted in dry seeds. [28] reported the similar results regarding shoot weight (Figure 6).

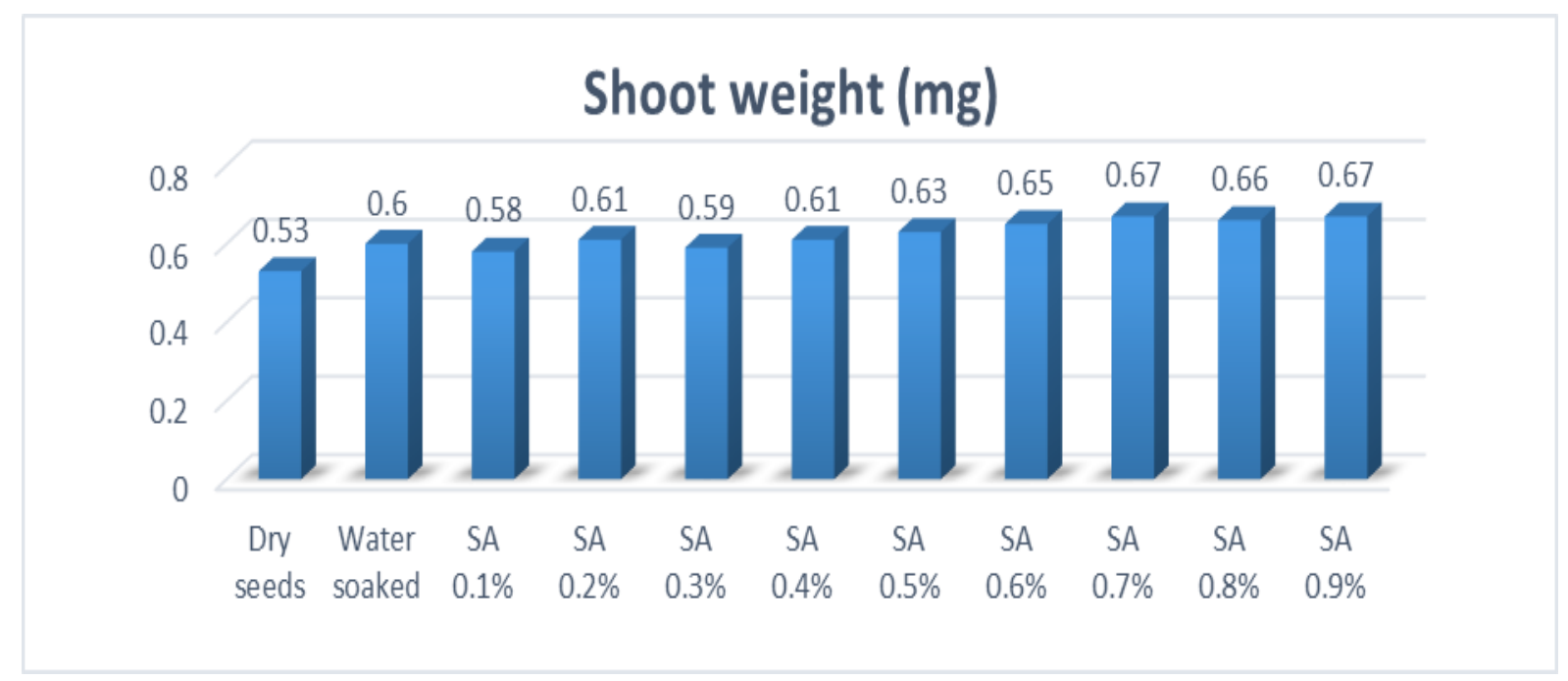

Figure 6. Shoot Weight (mg) as influenced by seed priming with salicylic acid on germination and early growth of sesame 


\section{Root weight (mg plant ${ }^{-1}$ )}

Data regarding root weight is presented in graph underneath. Analysis of the data showed significant result of dissimilar levels of salicylic acid solutions on root weight. Higher root weight $\left(0.38 \mathrm{mg}\right.$ plant $^{-}$ $\left.{ }^{1}\right)$ was noted in $0.9 \%$ of salicylic acid solutions, while the lower root weight $(0.25$ mg plant $^{-1}$ ) was recorded in dry seeds. [29] are in close agreement, who revealed that seeds of wheat treated earlier seeding with gibberellic acid and kinetin might be optional as earlier to root growth (Figure 7).

\section{Root weight (mg plant ${ }^{-1}$ )}

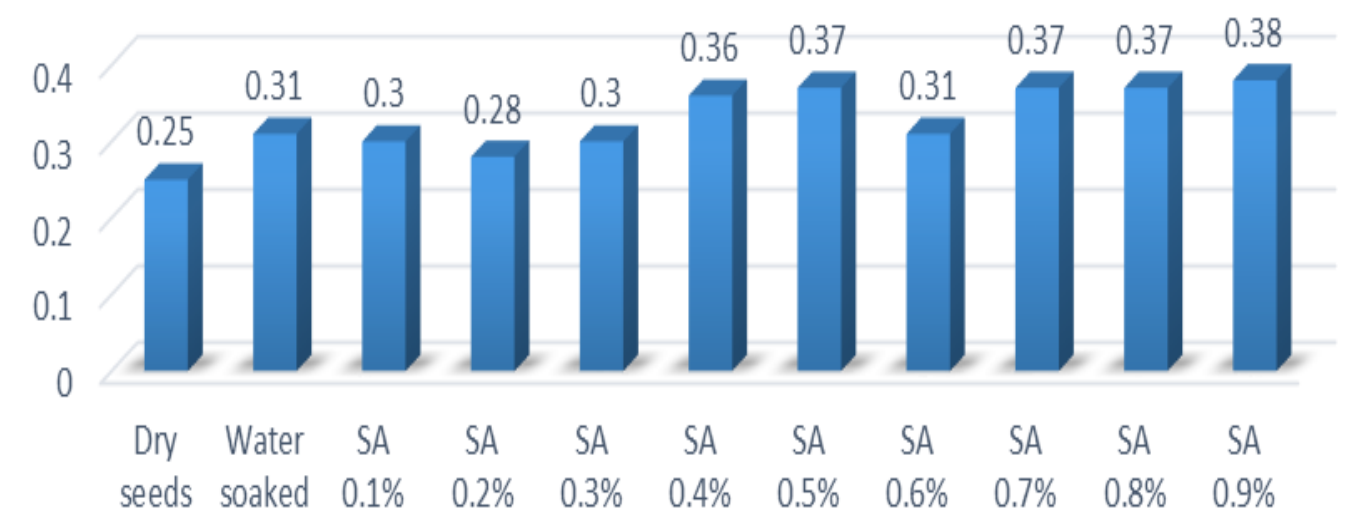

Figure 7. Root Weight (mg) as influenced by seed priming with salicylic acid on germination and early growth of sesame

\section{Shoot/root ratio}

Data regarding shoot to root ratio is presented in graph. Analysis of the data displayed significant result of salicylic acid on seed priming of sesame. Higher shoot to root ratio (2.79) was noted in $0.9 \%$ salicylic acid solutions, followed by (2.76) which is noted in $0.8 \%$ of salicylic acid solutions. Lower shoot to root ratio (2.1) was noted where the seeds not treated. These result in line with those of [30] who clearly indicated that increasing salicylic acid solution it increase both the weight of shoot and root (Figure 8).

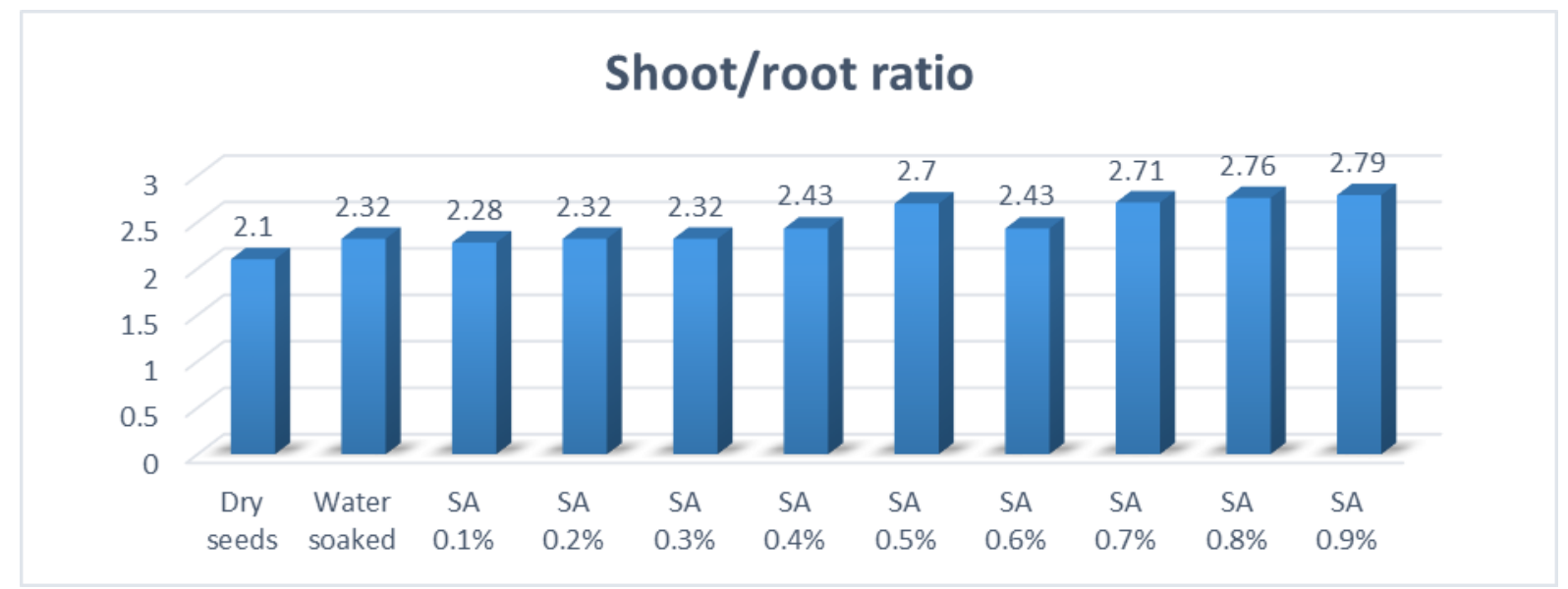

Figure 8. Shoot/root ratio as influenced by seed priming with salicylic acid on germination and early growth of sesame 


\section{Conclusion}

It is concluded from the findings of research that among the seed priming with different levels of salicylic acid solutions, the solutions from $0.6 \%$ to $0.9 \%$ of salicylic acid perform better on seed priming of sesame. Although further research is needed on levels of salicylic acid solutions for germination of sesame.

\section{Authors' contributions}

Conceived and designed the experiments: $\mathrm{F}$ Ahmad, S Iqbal \& MR Khan, Performed the experiments: F Ahmad \& S Iqbal, Analyzed the data: F Ahmad, MR Khan \& MW Abbas, Contributed materials/ analysis/ tools: H Nawaz, SMA Shah \& S Iqbal, Wrote the paper: J Ahmad, M Ahmad \& M Ali.

\section{References}

1. Nazir (1994). Effect of Salicylic acid levels on sesame cultivars. Indian J Bio Sci 9(3): 44-48.

2. Malik MA, Saleem MF, Cheema MA \& Ahmad S (2003). Influence of different nitrogen levels on productivity of sesame (sesame indicum L.) under varying planting patterns. Inter J Agri Biol 5(4): 490492.

3. Alpaslan M \& Gunes A (2001). Interactive effects of boron and salinity stress on the growth, membrane permeability and mineral composition of tomato and cucumber plants. Plant and Soil 236(1): 123-128.

4. Qadeer A (1998). Performance of six genotypes ofsesame under irrigated conditions. M.sc. (Hons.) Thesis Deptt. Of Agron. Agric. Uni., Peshawar, Pakistan.

5. MNFSR (2014). Agriculture Statistic of Pakistan. Ministry of National Food Security and Research. Fedral Bureau of Statistics, Economic Survey of Pakistan.

6. Betoni JS, Derr K, Pahl, Rogers MC, Muller L, Packard CL \& Tromp G (2013). Micro RNA analysis in placentas from patients with preeclampsia: comparison of new and published results. Hypertension in Pregnancy 32(4): 321-339.

7. Zheng S, Jayasumana, RomeraParedes, Vineet B, Su V, Du D, \& Torr PH (2015). Conditional random fields as recurrent neural networks. In Proceedings of the IEEE international conference on computer vision, $p p$ 1529-1537.

8. Kaya MD, Okçu G, Atak M, Cıkılı Y \& Kolsaricı O (2006). Seed treatments to overcome salt and drought stress during germination in sunflower (Helianthus annuus L.). European $J$ of Agron 24(4): 291-295.

9. Zeid IM \& Shedeed ZA (2006). Response of alfalfa to putrescine treatment under drought stress. Biol Plantar 50(4): 635.

10. Bradford \& Harman (1990). Impact of seed priming on DNA replications. Afr J Plant Sci 9(2): 233-238.

11. Ashraf M \& Foolad MR (2005). Presowing seed treatment-A shotgun approach to improve germination, plant growth, and crop yield under saline and non-saline conditions. $A d v$ in Agron 88: 223-271.

12. Chiu (2002) \& Murungu (2004). Temperature-dependent germination and endo-mannanase activity in sesame seeds. Brazil. Agri Bio Cel 70: 910-900.

13. Khan AA (1992). Preplant physiological seed conditioning. Horticul Rev 13(1): 131-181.

14. Thornton and Powell. 1992. Physiological and enzymatic alterations in sesame seeds submitted to different osmotic potentials. Genet. Mol Res 16(3): 162.

15. Joseph and Levent T (2007). Multiple regression analysis for studied traits in hormonal seed priming of sesame cultivars. ISSN (4): 101-105.

16. Salarzidah F, Mustafavi SH \& Abbasi A (2012). Sonication of seeds increase germination performance of sesame under low temperature stress. Agri J 105(2): 3 . 
17. Khallal E (2009). The effect of salinity stress on germination characteristics and changes of biochemically of sesame seeds. Cer. Agron. Moldova 9(20): 158-163.

18. Gharib \& Hanan (2007). Influence of salicylic acid and gabbrilic acid of sesame seed. Afr J Agr 2(4): 233-236.

19. Hanan BB, Shervais JW \& Vetter SK (2008). Yellowstone plumecontinental lithosphere interaction beneath the Snake River Plain. Geol 36(1): 51-54.

20. Sedghiet, (2010) \& Farooq (2008). Effect of foliar application with salicylic acid on some morphological and physiological characteristics of sesame under drought stress. 4(168): 35-42.

21. Farooq M \& Carey M (2008). A case of liver trauma with a blunt regional anesthesia needle while performing transversus abdominis plane block. Regional Anesthesia and Pain Med 33(3): 274-275.

22. Athar (2008). Effect of seed priming with PED or K3PO4 on germination and seedling growth in lettuce. Pak $J$ Bio Sci 9(9): 977-982.

23. Goussous SJ, Samarah NH, Alqudah AM \& Othman MO (2010). Enhancing seed germination of four crop species using an ultrasonic technique. Exper Agri 46(2): 231-242.
24. Yaldagard M, Mortazavi SA \& Tabatabaie F (2008). Influence of ultrasonic stimulation on the germination of barley seed and its alpha-amylase activity. African $J$ of Biotechnol 7(14).

25. Chugh LK \& Sawhney SK (1996). Effect of cadmium on germination, amylases and rate of respiration of germinating pea seeds. Environ Pollu 92(1): 1-5.

26. Mollar R, Souza GAD, Cardoso AA and Santos DCF. 2007. Action of nitric oxide in sesame seeds submitted to stress by cadmium. Afr Sci 43(8): 8893.

27. Tahir M, Ali I and Hamza. 2012. Influence of ascorbic acid on germination and proline of sesame seeds. IJA CS 4(8): 109-116.

28. Demir I \& Van de Venter HA (1999). The effect of priming treatments on the performance of watermelon (Citrullus lanatus (Thunb.) Matsum \& Nakai) seeds under temperature and osmotic stress. Seed Sci and Technol 27(3): 871-875.

29. Mirshekari (2014). Seed priming to diverse levels of growth promoters. $J$ Agr \& Bio 4(2): 32-38.

30. Basra SMA, Ashraf M, Iqbal N, Khaliq A \& Ahmad R (2004). Physiological and biochemical aspects of pre-sowing heat stress on cottonseed. Seed Sci and Technol 32(3): 765-774. 